\title{
First Report of Gastrointestinal Helminths from the Wokan Cannibal Frog, Lechriodus melanopyga (Amphibia: Limnodynastidae), from Papua New Guinea ${ }^{1}$
}

\author{
Stephen R. Goldberg, ${ }^{2}$ Charles R. Bursey, ${ }^{3}$ and Fred Kraus ${ }^{4}$
}

\begin{abstract}
The initial gastrointestinal helminth list is established for Lecbriodus melanopyga (Doria) from Papua New Guinea. Examination of the digestive tracts of 16 L. melanopyga from April-May $(n=14)$ and October $(n=2)$ revealed six helminth species: Digenea: Mesocoelium monas; Nematoda: Aplectana macintoshii, Cosmocerca novaeguineae, Oswaldocruzia bakeri, Abbreviata sp. (larvae in cysts); Acanthocephala: Acanthocephalus bufonis. Cosmocerca novaeguineae was present in the greatest numbers (171) and shared the highest prevalence (88\%) with Acanthocephalus bufonis. Lechriodus melanopyga represents a new host record for each of these helminths. New Guinea is a new locality record for Mesocoelium monas and Acanthocephalus bufonis.
\end{abstract}

The family Limnodynastidae consists of eight genera with over 40 species, of which Limnodynastes and Lechriodus occur in both Australia and New Guinea; all other genera are restricted to Australia (Zug et al. 2001, Frost et al. 2006). The Wokan cannibal frog, Lechriodus melanopyga (Doria) is a mediumsized, dull brown frog rarely more than 50 $\mathrm{mm}$ long that ranges across New Guinea (Zweifel 1972, Günther 2003) and breeds in shallow forest swamps and puddles (Menzies 1976; F.K., pers. obs.). There are, to our knowledge, no published records of helminths from this species. The purpose of this note is to report the first helminth records from L. melanopyga as part of an ongoing survey of the helminths of the herpetofauna of Papua New Guinea.

\footnotetext{
${ }^{1}$ This research was supported by NSF grant DEB0103794. This is contribution 2006-037 from the Pacific Biological Survey at the Bishop Museum. Manuscript accepted 14 August 2006.

${ }^{2}$ Corresponding author: Department of Biology, Whittier College, Whittier, California 90608 (phone: 562-907-4294; e-mail: sgoldberg@whittier.edu).

${ }^{3}$ Department of Biology, Pennsylvania State University, Shenango Campus, Sharon, Pennsylvania 16146.

${ }^{4}$ Hawai'i Biological Survey, Bishop Museum, Honolulu, Hawai'i 96817.
}

Pacific Science (2007), vol. 61, no. 3:429-432

(C) 2007 by University of Hawai'i Press

All rights reserved

\section{MATERIALS AND METHODS}

Sixteen Lechriodus melanopyga (mean snoutvent length, $50.0 \pm 2.46 \mathrm{SD}$; range, 46.6$56.0 \mathrm{~mm}$ ) were collected by hand by F.K. from 29 April to 2 May 2002 and 5 October 2002 at Duabo, $10.4184333^{\circ} \mathrm{S}, 150.3068333^{\circ}$ E (WGS 84 datum), $300 \mathrm{~m}$, Pini Range, Milne Bay, Papua New Guinea. Frogs were fixed in $10 \%$ neutral buffered formalin and preserved in $70 \%$ ethanol. The body cavity was opened by a lateral incision, and the digestive tract was removed, opened longitudinally, and examined under a dissecting microscope. Helminths were removed, placed on a glass slide in a drop of undiluted glycerol, covered with a coverslip, and examined under a compound microscope. Nematodes were identified from the glycerol slides; digeneans and acanthocephalans were regressively stained in Delafeld's hematoxylin, mounted in Canada balsam, and identified. Frogs were deposited in the Bernice P. Bishop Museum (врвм), Honolulu, Hawai'i, as 15453-66 (April-May 2002) and 16259-60 (October 2002). Helminths were placed in vials of $70 \%$ ethanol and deposited in the United States National Parasite Collection (USNPC), Beltsville, Maryland, and the Bernice P. Bishop Museum (врвм), Honolulu, Hawai'i: Mesocoelium monas, usNPC 97835, врвм F239; Aplectana macintoshii, USNPC 97836, врвм H143; Cosmocerca novaeguineae, UsNPC 97837, 
вРвм H144; Oswaldocruzia bakeri, USNPC 97838, вРвм H145; Abbreviata sp. (larva), usNPC 97839, врвм H146; Acanthocephalus bufonis, USNPC 97840, в Рвм H147.

\section{RESULTS}

One species of Digenea, Mesocoelium monas (Rudolphi, 1819) Freitas, 1957; four species of Nematoda, Aplectana macintoshii (Stewart, 1914) Travassos, 1931, Cosmocerca novaeguineae Moravec \& Sey, 1990, Oswaldocruzia bakeri Moravec \& Sey, 1986, Abbreviata sp. (larvae in cysts); and one species of Acanthocephala, Acantbocephalus bufonis (Shipley, 1903) Southwell \& Macfie, 1925 were found.

Number of helminths, prevalences, mean intensity $\pm 1 \mathrm{SD}$, range, mean abundance \pm 1 $\mathrm{SD}$, and infection site are given in Table 1. Cosmocerca novaeguineae was present in the greatest numbers (171) and shared the highest prevalences (88\%) with Acanthocephalus bufonis.

\section{DISCUSSION}

A total of 256 helminths was collected; of these, 35 (14\%) were larval forms (Abbreviata sp.) not capable of reaching maturity in frogs; the other species were represented by various developmental stages including gravid individuals. There were six helminth species represented in the sample, but no individual host harbored more than four species. All frogs were infected: two (12\%) harbored one species of helminth; seven (44\%) harbored two species; six (38\%) harbored three; and one (6\%) harbored four species. There were $2.38 \pm 0.2( \pm 1$ SE) helminth species per infected frog and $16.0 \pm 3.4$ helminth individuals per infected frog. Aho (1990) compiled distributional patterns for frog helminths in general and reported the mean \pm 1 SE as $3.54 \pm 0.24$ (range 0-9) per host species. The values reported herein are within the range of Aho (1990), although the mean infective rate is lower than Aho (1990) reported. The lower rate may be a reflection of regional differences in frog infection rates or something as simple as sample size differences.

Mesocoelium monas is known from fishes, amphibians, and reptiles (Goldberg et al. $2005 b$ ). It appears to be cosmopolitan in distribution. Aplectana macintoshii was previously found in the gecko Cyrtodactylus louisiadensis from New Guinea by Bursey et al. (2005). It is the most cosmopolitan member of the genus and has been reported from species of frogs, toads, lizards, and one species of snake;

TABLE 1

Number, Prevalence (Percentage), Mean Intensity \pm 1 SD, Range, Mean Abundance \pm 1 SD, and Infection Site for Gastrointestinal Helminths from $1 \bar{\sigma}$ Lechriodus melanopyga from Papua New Guinea

\begin{tabular}{|c|c|c|c|c|c|}
\hline $\begin{array}{l}\text { Helminth } \\
\text { Infection Site }\end{array}$ & Number & $\begin{array}{l}\text { Prevalence } \\
\quad(\%)\end{array}$ & $\begin{array}{c}\text { Mean } \\
\text { Intensity } \pm 1 \mathrm{SD}\end{array}$ & Range & $\begin{array}{c}\text { Mean } \\
\text { Abundance } \pm 1 \mathrm{SD}\end{array}$ \\
\hline \multicolumn{6}{|l|}{ Digenea } \\
\hline $\begin{array}{l}\text { Mesocoelium monas } \\
\text { Small intestine }\end{array}$ & 4 & 6 & 4.0 & - & $0.25 \pm 1.0$ \\
\hline \multicolumn{6}{|l|}{ Nematoda } \\
\hline $\begin{array}{l}\text { Aplectana macintoshii } \\
\text { Large intestine }\end{array}$ & 8 & 13 & 4.0 & - & $0.50 \pm 1.4$ \\
\hline $\begin{array}{l}\text { Cosmocerca novaeguineae } \\
\text { Large intestine }\end{array}$ & 171 & 88 & $12.2 \pm 10.7$ & $1-42$ & $10.69 \pm 10.9$ \\
\hline $\begin{array}{l}\text { Oswaldocruzia bakeri } \\
\text { Small, large intestines }\end{array}$ & 2 & 13 & 1.0 & - & $0.12 \pm 0.3$ \\
\hline $\begin{array}{l}\text { Abbreviata sp. (larvae in cysts) } \\
\text { Stomach wall }\end{array}$ & 35 & 31 & $7.0 \pm 6.5$ & $1-18$ & $2.19 \pm 4.8$ \\
\hline $\begin{array}{l}\text { Acanthocephala } \\
\text { Acantbocephalus bufonis } \\
\text { Small intestine }\end{array}$ & 36 & 88 & $2.6 \pm 1.8$ & $1-7$ & $2.25 \pm 1.9$ \\
\hline
\end{tabular}


it is known from Africa, China, Europe, Japan, India, South America, and Malaysia (Baker 1987, Goldberg et al. 1993). Cosmocerca novaeguineae was described from the ranid frog Platymantis papuensis from Papua New Guinea by Moravec and Sey (1990). Oswaldocruzia bakeri was described by Moravec and Sey (1986) from the microhylid frogs Callulops stictogaster and Callulops wilhelmana from Papua New Guinea. It was also found by Moravec and Sey (1986) in one other microhylid frog species from Papua New Guinea, Callulops bumicola. Encysted larvae of Abbreviata sp. were reported in the gecko Cyrtodactylus louisiadensis from Papua New Guinea by Bursey et al. (2005) and are common in Australian lizards (Jones 1992, 1995a,b, Goldberg and Bursey 2001). Acanthocephalus bufonis was originally described from the toads Bufo melanostictus and Bufo penangensis from Thailand by Shipley (1903) and redescribed by Kennedy (1982) from $B$. melanostictus from Indonesia. It has been reported from Belau in the anuran Platymantis pelewensis by Bursey and Goldberg (2004); from China in Rana formosus and R. nigromaculata by Van Cleave (1937); from Hawai'i in Chaunus marinus (formerly Bufo marinus) by Barton and Pichelin (1999) and in Rana rugosa by Goldberg et al. (2005a); from Malaysia in Bufo asper, Kaloula pulcra, Rana cancrivora, Rana chalconota, Rana erytbraea, Rana macrodon, and Rana tigrina by Yuen and Fernando (1967); as well as in lizards from Indonesia (Takydromus sexlineatus) by Kennedy (1982) and from Hawai'i (Anolis sagrei) by Goldberg and Bursey (2000). Lechriodus melanopyga represents a new host record for each of the helminths listed here. New Guinea is a new locality record for Mesocoelium monas and Acanthocephalus bufonis. Subsequent work is required to ascertain the diversity of helminths found in the amphibians and reptiles of Papua New Guinea.

\section{ACKNOWLEDGMENTS}

We thank S. Kark and E. Teodoro for assistance with dissections; J. Slapcinsky for field assistance; B. Lebasi for graciously facilitating work on his land; the Papua New Guinea Na- tional Museum and Art Gallery for providing in-country collaborative assistance; and the Department of Environment and Conservation, National Research Institute, and Milne Bay Provincial Government for permission to conduct this research.

\section{Literature Cited}

Aho, J. M. 1990. Helminth communities of amphibians and reptiles: Comparative approaches to understanding patterns and processes. Pages 157-195 in G. W. Esch, A. O. Bush, and J. M. Aho, eds. Parasite communities: Patterns and processes. Chapman and Hall, London.

Baker, M. R. 1987. Synopsis of the Nematoda parasitic in amphibians and reptiles. Memorial Univ. Newfoundland Occas. Pap. Biol. 11:1-325.

Barton, D. P., and S. Pichelin. 1999. Acanthocephalus bufonis (Acanthocephala) from Bufo marinus (Bufonidae: Amphibia) in Hawaii. Parasite 6:269-272.

Bursey, C. R., and S. R. Goldberg. 2004. A new species of Spinicauda (Nematoda: Heterakidae) and other endoparasites in Platymantis pelewensis (Anura: Ranidae) from the Palau Islands, Republic of Belau, Oceanica. J. Parasitol. 90:1428-1433.

Bursey, C. R., S. R. Goldberg, and F. Kraus. 2005. New genus, new species of Cestoda (Anoplocephalidae), new species of Nematoda (Cosmocercidae) and other helminths in Cyrtodactylus louisiadensis (Sauria: Gekkonidae) from Papua New Guinea. J. Parasitol. 91:882-889.

Frost, D. R., T. Grant, J. Faivovich, R. H. Bain, A. Haas, C. F. B. Haddad, R. O. de Sá, A. Channing, M. Wilkinson, S. C. Donnellan, C. J. Raxworthy, J. A. Campbell, B. L. Blotto, P. Moler, R. C. Drewes, R. A. Nussbaum, J. D. Lynch, D. M. Green, and W. C. Wheeler. 2006. The amphibian tree of life. Bull. Am. Mus. Nat. Hist. 297:1-370.

Goldberg, S. R., and C. R. Bursey. 2000. Transport of helminths to Hawaii via the brown anole, Anolis sagrei (Polychrotidae). J. Parasitol. 86:750-755.

- 2001. Intestinal helminths of seven 
species of gekkonid lizards (Sauria: Gekkonidae) from Western Australia. J. R. Soc. West. Aust. 84:23-27.

Goldberg, S. R., C. R. Bursey, and F. Kraus. 2005a. Rana rugosa (wrinkled frog). Endoparasites. Herpetol. Rev. 36:56.

Goldberg, S. R., C. R. Bursey, and R. Tawil. 1993. Aplectana macintoshii (Nematoda: Cosmocercidae) in Eumeces latiscutatus (Sauria: Scincidae) from Japan. J. Helminthol. Soc. Wash. 60:283-284.

Goldberg, S. R., C. R. Bursey, and S. R. Telford, Jr. 2005 $b$. Metazoan endoparasites of four species of lizards, Gebyra mutilata, Hemidactylus frenatus (Gekkonidae), $M a-$ buya cumingi, Mabuya multifasciata (Scincidae), and one species of snake, Ramphotyphlops braminus (Typhlopidae), from the Philippine Islands. Comp. Parasitol. 72:88-101.

Günther, R. 2003. Notable distribution records of New Guinean frog species and genera beyond their known ranges (Amphibian: Anura). Faun. Abh. (Dres.) 24:209-216.

Jones, H. I. 1992. Gastrointestinal nematodes in the lizard genera Tiliqua and Cyclomorphus (Scincidae) in Western Australia. Aust. J. Zool. 40:115-126.

. 1995a. Gastric nematode communities in lizards from the Great Victoria Desert, and an hypotheses for their evolution. Aust. J. Zool. 43:141-164.

1995b. Pathology associated with physalopterid larvae (Nematoda: Spirurida) in the gastric tissues of Australian reptiles. J. Wildl. Dis. 31:299-306.

Kennedy, M. J. 1982. A redescription of
Acantbocephalus bufonis (Shipley, 1903) Southwell and Macfie, 1925 (Acanthocephala; Echinorhynchidae) from the blackspotted toad, Bufo melanostictus, from Bogor, Indonesia. Can. J. Zool. 60:356-360.

Menzies, J. I. 1976. Handbook of common New Guinea frogs. Wau Ecology Institute, Handbook No. 1, Wau, Papua New Guinea.

Moravec, F., and O. Sey. 1986. Three new nematode species from Phrynomantis spp. (Amphibia: Microhylidae) from Papua New Guinea. Folia Parasitol. (Prague) 33:343-351.

- 1990. Some nematode parasites of frogs from Papua New Guinea and Australia. Acta Soc. Zool. Boehms. 54:268-286.

Shipley, A. E. 1903. On the ento-parasites collected by the "Skeat Expedition" to lower Siam and the Malay Peninsula in the years 1899-1900. Proc. Zool. Soc. Lond. 2:145-146.

Van Cleave, H. J. 1937. Acanthocephala from China II. Two new species from the genus Acanthocephalus from Amphibia. Parasitology 29:395-398.

Yuen, P. H., and C. H. Fernando. 1967. On Acanthocephalus bufonis (Shipley) a common parasite of Malayan amphibians. Bull. Natl. Mus. Singapore 33:92-93.

Zug, G. R., L. J. Vitt, and J. P. Caldwell. 2001. Herpetology: An introductory biology of amphibians and reptiles. 2nd ed. Academic Press, San Diego, California.

Zweifel, R. G. 1972. A review of the frog genus Lechriodus (Leptodactylidae) of New Guinea and Australia. Am. Mus. Novit. 2507:1-41. 